\title{
Stream Monitoring for Detection of Phytophthora ramorum in Oregon Tanoak Forests
}

\author{
W. Sutton, E. M. Hansen, and P. W. Reeser, Department of Botany and Plant Pathology, Oregon State University, \\ Corvallis 97331; and A. Kanaskie, Oregon Department of Forestry, Salem
}

\begin{abstract}
Sutton, W., Hansen, E. M., Reeser, P. W., and Kanaskie, A. 2009. Stream monitoring for detection of Phytophthora ramorum in Oregon tanoak forests. Plant Dis. 93:1182-1186.

Stream monitoring using leaf baits for early detection of Phytophthora ramorum has been an important part of the Oregon Sudden Oak Death (SOD) program since 2002. Sixty-four streams in and near the Oregon quarantine area in the southwest corner of the state were monitored in 2008. Leaves of rhododendron (Rhododendron macrophyllum) and tanoak (Lithocarpus densiflorus) were placed in mesh bags, and bags were floated in streams. Leaf baits were exchanged every 2 weeks throughout the year. Leaves were assayed by isolation on selective medium and by multiplex rDNA internal transcribed spacer polymerase chain reaction (ITS PCR). The two methods gave comparable results, but multiplex PCR was more sensitive. P. ramorum was regularly recovered at all seasons of the year from streams draining infested sites 5 years after eradication treatment. In streams with lower inoculum densities, recovery was much higher in summer than in winter. P. ramorum was isolated from streams in 23 watersheds. When $P$. ramorum was detected, intensive ground surveys located infected tanoaks or other host plants an average of $306 \mathrm{~m}$ upstream from the bait station. P. ramorum was isolated from stream baits up to 1,091 $\mathrm{m}$ from the probable inoculum source.
\end{abstract}

Phytophthora ramorum Werres, DeCock, \& Man in't Veld (24) is a recently described invasive pathogen causing sudden oak death (SOD) in some forests in the western United States. In Oregon, an ongoing early detection, local eradication, and area containment program (16) seeks to limit the further spread of the pathogen. Stream monitoring for $P$. ramorum using leaf baits is an important part of the early detection effort.

$P$. ramorum is established in mixed hardwood forests of coastal California $(21,22)$ and southwest Oregon $(8,12)$. It is also present in plant nurseries on the West Coast of North America $(1,14)$. Although the pathogen has been distributed widely across the United States and Canada on infected nursery stock, to date it has not been detected in forests except in California and Oregon. In Europe, P. ramorum is present in the horticulture trade and in some landscape situations (2).

$P$. ramorum is a pathogen of aerial parts of woody plants, forming deciduous sporangia on infected leaf and twig tissue (22). It is regularly recovered from rain water beneath infected trees $(4,12)$. In Oregon, $P$. ramorum kills tanoak (Litho-

Corresponding author: E. M. Hansen

E-mail: hansene@science.oregonstate.edu

Accepted for publication 14 July 2009.

doi:10.1094/PDIS-93-11-1182

(C) 2009 The American Phytopathological Society carpus densiflorus) and may infect wild rhododendron (Rhododendron macrophyllum), evergreen huckleberry (Vaccinium ovatum), myrtlewood (Umbellularia californica), and other native plants growing in close association with tanoak $(12,13)$. The host list (http://www.aphis.usda.gov/ plant_health/plant_pest_info/pram/) includes at least 40 species of native forest plants that are infected in nature in California and Oregon.

$P$. ramorum is subject to state, federal, and international quarantines, and there is concern that it may spread to the large areas of known hosts beyond the current distribution in coastal forests in California and Oregon, as well as to forests in other parts of North America and around the world where susceptible plants grow. In 2001, P. ramorum was found in southwest Oregon near the town of Brookings (8; Fig. 1), and it is still confined to tanoak forests within $15 \mathrm{~km}$ of Brookings (12). Here the pathogen is subject to intensive detection monitoring using aerial and ground surveys and stream monitoring, quarantine to prevent transport of infected plant materials, and local eradication based on cutting and burning diseased tanoak trees and associated host plants as they are found $(9,16)$. The effort has slowed the spread of $P$. ramorum in Oregon (10), but new infections are found each year. Disease patches covering a total of about 67 ha were treated from 2001 through 2007 (16).

Baiting or filtering irrigation water for pathogenic Phytophthora species is a use- ful monitoring tool in several agricultural crop systems, including horticultural nurseries (15). Continuous monitoring of forest streams for the early detection of $P$. ramorum has become an important part of the Oregon SOD detection and eradication program (23). Similar stream monitoring programs for $P$. ramorum are underway in Washington and California (18). Our experience contributed to the national stream monitoring protocol recently implemented by the USDA Forest Service to support early detection of $P$. ramorum in other states (19). Here we describe the methods and results of our stream monitoring efforts in Oregon.

\section{MATERIALS AND METHODS}

Description of the forest. The climate in the $P$. ramorum-infested area of southwest Oregon is wet and mild in the winter and relatively dry and warm in the summer with frequent fog. The forest is part of the Mixed-Evergreen (Pseudotsuga-sclerophyll) Zone (7). Tanoak, often with Douglas-fir (Pseudotsuga menziesii), dominates the infested sites. Red alder (Alnus rubra) is also common and Oregon myrtlewood is scattered throughout the area (12). The terrain is steep and strongly dissected. Elevations range from sea level to about $500 \mathrm{~m}$.

The forest is a mosaic of different vegetation types and ages. About $20 \%$ of the area is Douglas-fir plantations $<40$ years old, and another $20 \%$ is dominated by tanoak stands that succeeded Douglas-fir forests after wildfires and the first timber harvests in the early 1900s. The remaining area is covered by mixed stands of tanoak, mature Douglas-fir, red alder, and bigleaf maple (Acer macrophyllum) (12).

Stream baiting. Streams were selected for monitoring in and around the SOD quarantine area established by the Oregon Department of Agriculture in southwestern Curry County (Fig. 1). Streams were selected for monitoring in areas considered to be at high risk for future infestation, including watersheds with concentrations of tanoak and near the perimeter of the infested area. Most baiting was in the upper reaches of perennial streams. Watersheds upstream from baiting stations ranged in area from 8 to 3,634 ha and averaged 503 ha. Bait stations on streams were often upstream from road crossings for accessibility. Some streams could not be sampled during prolonged summer 
droughts or during winter storm rain events.

Many baiting stations were moved between years as priorities shifted and new streams were added to the sampling network. Two or three baiting stations were sometimes placed along a single stream to localize the source of P. ramorum. A total of 84 streams have been monitored since 2002 (Fig. 1). In 2008, 64 streams were baited. Thirty-two streams were baited continuously from March 2004 through February 2008. One set of stream monitoring stations was established in streams draining infested sites identified in 2001. All host plants within 20 to $40 \mathrm{~m}$ of symptomatic plants on these sites had been cut and burned in that year as part of the eradication effort. Five of these streams were baited continuously from 2003 through 2007.

Blemish-free leaves of wild rhododendron and tanoak were collected at each sample time from outside the quarantine area. Two leaves of each species were placed in open weave nylon mesh bags, and bags were floated in relatively quiet water anchored to a stake or streamside tree. Stream temperature near the sample bag was monitored continuously in 2006 in seven streams using water temperature recorders (Hobo Water Temp Pro U22-001; Onset Computer Corp, Bourne, MA). Bags and leaves were exchanged every 2 weeks throughout the year. Leaves were sent by overnight delivery to Oregon State University for diagnostic testing.

Identification of $P$. ramorum. Two diagnostic techniques were used: (i) isolation on selective medium; and (ii) multiplex polymerase chain reaction (PCR) diagnosis using the Winton and Hansen primers (25). Rhododendron and tanoak leaf baits were rinsed in tap water and examined for necrotic areas. Petioles and symptomatic tissues were excised, and portions about 2 by $2 \mathrm{~mm}$ were placed on agar for isolation or in a 2-ml screw-cap vial for DNA extraction with a DNeasy Tissue Extraction Kit (Qiagen Inc., Valencia, CA).

When selecting leaf pieces for isolation and PCR, necrotic areas were favored, but the petiole, whether necrotic or not, always was included. Leaf pieces were plated on CARP+ selective medium (12; cornmeal agar with natamycin, ampicillin, rifamycin, benomyl, and hymexazol). Isolation plates were placed at $20^{\circ} \mathrm{C}$ in the dark. Plates were examined at approximately 3 and 7 days for P. ramorum and other Phytophthora species. P. ramorum was initially identified on the isolation plates by its distinctive growth form and abundant production of chlamydospores and caducous, semi-papillate sporangia. Phytophthora species were transferred to CARP medium (CARP+ without benomyl and hymexazol) for further purification and eventually to cornmeal agar with 20 ppm $\beta$-sitosterol for confirmation.
The multiplex PCR assay has one set of primers that amplifies plant DNA as a check on reaction conditions and a second set for the target Phytophthora species. The assay was performed in $15 \mu \mathrm{l}$ reactions of $1 \times$ enzyme buffer, $200 \mu \mathrm{M}$ dNTP, $0.4 \mu \mathrm{M}$ PLITS87F and PLITS786R (Phytophthora primers), $0.07 \mu \mathrm{M}$ NS1 and NS2 (universal primers), $0.15 \mu \mathrm{l} 5 \%$ blocking powder (Schleicher and Schuell, Keene, $\mathrm{NH}), 0.8$ Units RedTaq DNA polymerase, and $2 \mu \mathrm{DNA}$ template. The thermal cycler conditions were $2 \mathrm{~min}$ at $94^{\circ} \mathrm{C}, 35$ cycles of $94^{\circ} \mathrm{C}$ for $30 \mathrm{~s}, 52^{\circ} \mathrm{C}$ for $30 \mathrm{~s}$, and $72^{\circ} \mathrm{C}$ for $1 \mathrm{~min}$, followed by $72^{\circ} \mathrm{C}$ for $4 \mathrm{~min}$ and $24^{\circ} \mathrm{C}$ for $1 \mathrm{~min}$. The products were visualized with ethidium bromide under UV light in a $1.5 \%$ agarose gel.

\section{RESULTS}

Comparing diagnostic methods. Results from isolation and multiplex PCR were compared for stream bait samples collected at 2-week intervals during 4 years of monitoring $(n=1,804)$ (Table 1$)$. $P$. ramorum was detected by one or both tests in $18 \%$ of the samples $(6.1 \%$ by isolation, $17.1 \%$ by PCR, $5.3 \%$ by both methods). The results from isolation and PCR agreed unambiguously for $87 \%$ of samples. Because of its distinctive morphology, P. ramorum could often be identified on isolation plates even when growing among other microorganisms. PCR reliably detected $P$. ramorum in baits when it was visible in culture but could not be separated from competing organisms. The rate of false negative results for PCR was $0.8 \%$. Species of Phytophthora other than $P$. ramorum were cultured from $71 \%$ of all samples (data not shown). In $11.8 \%$ of all samples, results from the PCR assay were positive, but $P$. ramorum was not identified in culture, perhaps due to overgrowth by other Phytophthora species.

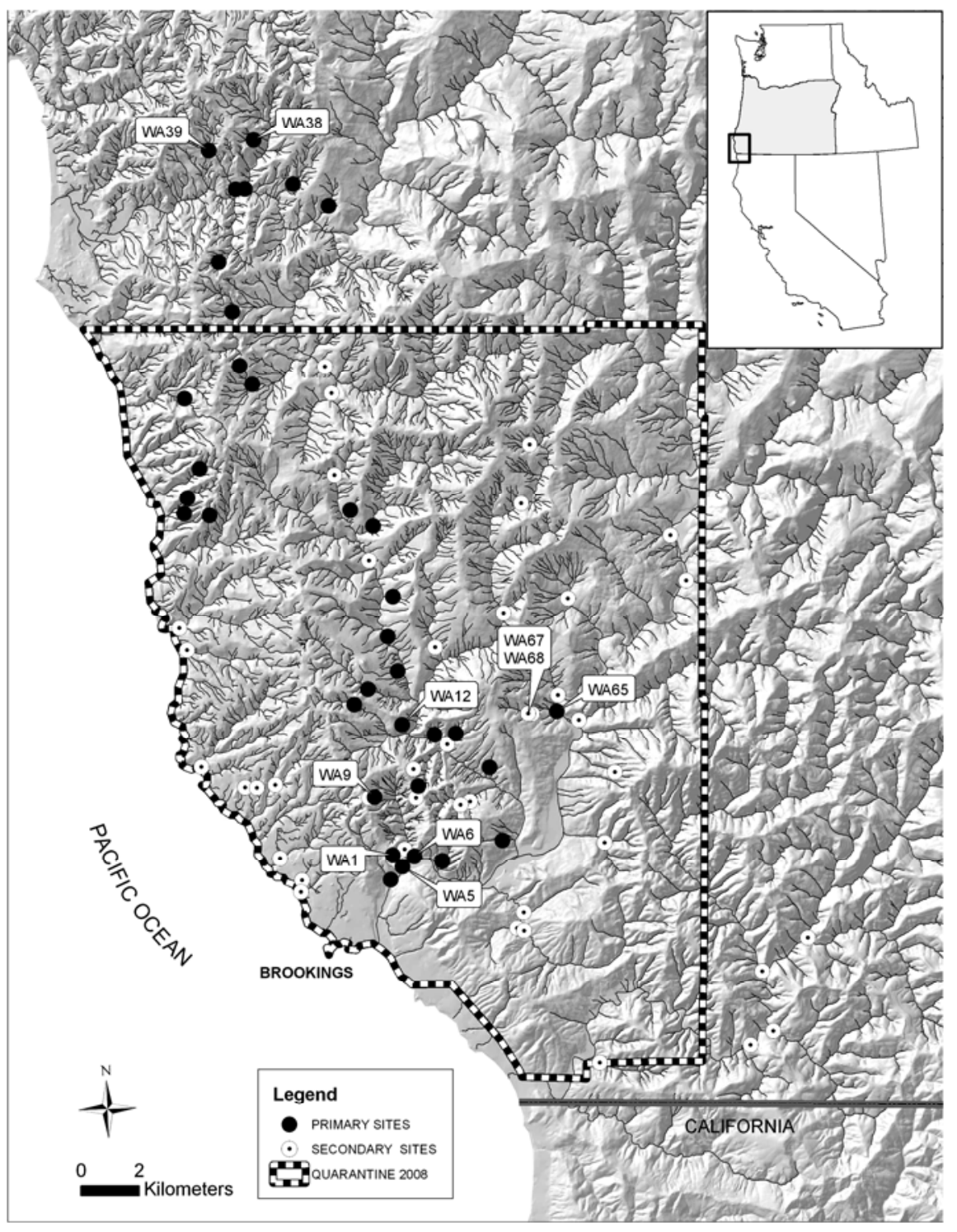

Fig. 1. Phytophthora ramorum stream monitoring sites in southwest Oregon. Primary sites include 32 monitored continuously from 2004 to 2008 and three others highlighted in the text (WA 38, WA 39, and WA 65). Thirty-six secondary sites were monitored for various lengths of time during this period. 
Phytophthora species, including $P$. ramorum, usually were associated with black necrotic areas on bait leaves. Lesions caused by $P$. ramorum did not have a unique appearance, and we did occasionally recover $P$. ramorum from green tissues, especially from leaf petioles. $P$. ramorum was regularly recovered from both tanoak and rhododendron leaf baits, but a quantitative comparison was not made. In general, symptoms were more visible on rhododendron leaves, and the leaves were easier to handle. In late winter and early spring, however, old rhododendron leaves had started to senesce, and the new growth was tender and often disintegrated in the streams. The stiff leaves of tanoak were an advantage at these times.

Persistence of $\boldsymbol{P}$. ramorum in streams. In $2007, P$. ramorum was detected in five streams draining sites where infected tanoaks and other host plants had been cut and burned as part of eradication treat-

Table 1. Detection of Phytophthora ramorum by isolation on selective medium and multiplex polymerase chain reaction (PCR) in rhododendron and tanoak leaves used to bait 82 forest streams in southwest Oregon over 5 years from 2003 through 2007

\begin{tabular}{llc}
\hline \multicolumn{2}{c}{ Detection of $\boldsymbol{P}$. ramorum } & $\begin{array}{c}\text { Percent samples } \\
(\boldsymbol{n}=\mathbf{1 , 8 0 4})\end{array}$ \\
\hline Isolation & PCR & 5.3 \\
Positive & Positive & 0.8 \\
Positive & Negative & 11.8 \\
Negative & Positive & 82.2 \\
Negative & Negative & \\
\hline
\end{tabular}

ments in 2001. Tanoak stump sprouts infected by $P$. ramorum were present on some of these sites in 2003, but these were destroyed in that year. Infected plants were not located during repeated monitoring surveys of the sites in subsequent years. $P$. ramorum persisted in the soil, although recovery was low $(<10 \%)$ in repeated testing (12). Overall detection rate by multiplex PCR declined from $63 \%$ of 2 -week sample intervals in 2003 (range for the five streams was 27 to $87 \%$ ), the first year of stream baiting, to $41 \%$ in 2007 (range was 25 to $67 \%$ ). Recovery of $P$. ramorum was lowest in 2005 (27\%, with a range of 5 to $50 \%)$.

Seasonal detection. $P$. ramorum was detected in leaf baits from the five streams draining old eradication sites by both isolation and multiplex PCR during all seasons of the year (Table 2). Uneven sample sizes resulted because baiting sometimes was impossible in late fall and winter due to fluctuating water levels associated with winter storms. In streams where $P$. ramorum was isolated less frequently, however, a seasonal trend was evident. Detection of $P$. ramorum was usually lowest from December through April, with peak recovery rates from July through October (Fig. 2). Periods of low recovery frequency corresponded with cooler water temperatures (data shown for 2006 only) and high winter flow rates in the streams (data not shown).

Early detection tool. Stream baits from 27 baiting stations representing 23 differ-

Table 2. Numbers and percentages of 2-week intervals by season over 5 years, from January 2003 to December 2007, in which Phytophthora ramorum was detected by isolation on selective medium or by multiplex polymerase chain reaction (PCR) in five streams (WA 1, 5, 6, 9, 12) draining infested eradication sites in southwest Oregon

\begin{tabular}{lccccc}
\hline & \multicolumn{2}{c}{ Isolation } & & \multicolumn{2}{c}{ PCR } \\
\cline { 2 - 3 } \cline { 5 - 6 } Seasona & $\begin{array}{c}\text { Intervals } \\
\text { sampled }\end{array}$ & $\begin{array}{c}\text { \% Positive } \\
\text { intervals }\end{array}$ & & $\begin{array}{c}\text { Intervals } \\
\text { sampled }\end{array}$ & $\begin{array}{c}\text { \% Positive } \\
\text { intervals }\end{array}$ \\
\hline Winter & 66 & 32 & & 109 & 35 \\
Spring & 54 & 33 & & 119 & 49 \\
Summer & 36 & 25 & & 104 & 48 \\
Fall & 44 & 30 & & 109 & 36 \\
\hline
\end{tabular}

${ }^{a}$ Winter: Jan, Feb, Mar; Spring: Apr, May, June; Summer: Jul, Aug, Sep; and Fall: Oct, Nov, Dec. ent streams (or stream segments) have tested positive for $P$. ramorum by isolation (and multiplex PCR). Eleven streams with $P$. ramorum confirmed by isolation drained known infested areas, and baiting stations in these streams were monitored as positive controls. Twelve streams that tested positive for $P$. ramorum by isolation drained watersheds that appeared to be free of SOD. Follow-up ground surveys in seven of these led to discovery of infected tanoaks. Positive isolations were obtained from an additional five bait stations on four different streams, but ground surveys failed to locate a source of inoculum within the drainage area.

Stream baits from 39 baiting stations tested positive one or more times by multiplex PCR, but the pathogen could not be isolated. In 15 of these sites, $P$. ramorum was detected only once by PCR throughout the entire survey period, and infected plants were found near only four of these streams. The remaining 24 bait stations had multiple positive results from the multiplex PCR assay but without successful isolation. In eight of these cases, infected trees were found by ground survey.

Stream WA 65 flows directly into the Chetco River and illustrates the utility of stream baiting for early detection of $P$. ramorum in tanoak forests. WA 65 drains a 200-ha watershed including an old-growth redwood-tanoak-Douglas-fir stand on state and federal land (Fig. 1). This area was covered by aerial survey flights conducted twice a year starting in 2001, with no detections of SOD. Baiting for P. ramorum started in May 2004, and the first positive isolation and PCR detections were in October 2005 (Table 3). Ground searches were conducted, but infected plants (understory tanoaks) were not located until April 2006. The site received eradication treatments that year. Leaf baits from WA 65 continued to test positive for $P$. ramorum for over a year after all host plants on the site were destroyed. At the time, WA 65 represented the most eastern SOD infestation in Curry County, which led to expansion of the quarantine area. In May 2006, two additional baiting stations

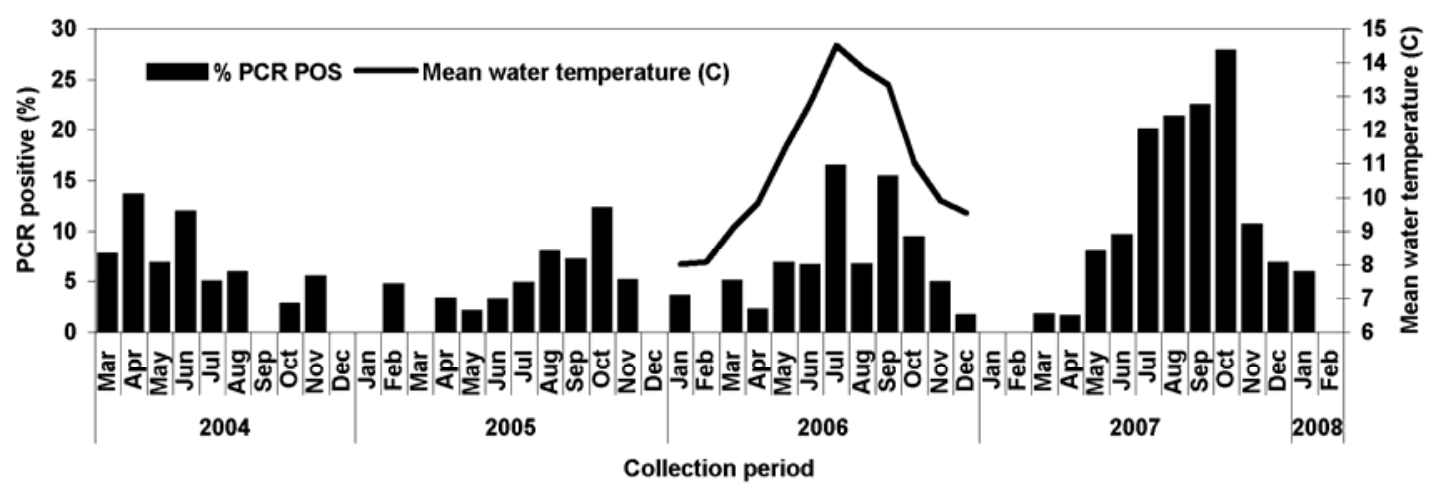

Fig. 2. Seasonal variation in detection of Phytophthora ramorum by multiplex polymerase chain reaction (PCR) from leaf baits in 32 streams monitored from March 2004 to February 2008 in southwest Oregon and monthly mean water temperatures for those streams in 2006 . No samples were collected in September 2004. 
(WA 67 and WA 68) were established in the same drainage but upstream of the eradication area around WA 65 . They have been periodically positive for $P$. ramorum by both isolation and PCR, but despite repeated surveys, additional infected trees have not yet been found.

The nearest infected trees within the upstream drainage area of 29 streams positive for $P$. ramorum by isolation or PCR were determined from detailed area maps, and stream distances from tree to bait station were measured using ArcGIS. The mean distance was $994 \mathrm{~m}$; maximum distance was $5,435 \mathrm{~m}$. The mean distance in streams where $P$. ramorum initially was detected by PCR only was $2,525 \mathrm{~m}(\max 5,435 \mathrm{~m})$; in streams where $P$. ramorum was isolated from baits, the mean distance was $306 \mathrm{~m}$ $(\max 1,091 \mathrm{~m})$. In three additional drainages, $P$. ramorum first was detected by aerial survey, while downstream bait stations remained negative. In these cases where baiting failed to give early warning, the mean stream distance from infected trees to the bait station was $3,322 \mathrm{~m}$.

\section{DISCUSSION}

Stream baiting has proved to be a valuable tool for early detection of $P$. ramorum in the Oregon eradication effort. We recovered $P$. ramorum from baits in streams of all sizes, from the main stem of the Chetco River to ephemeral streams draining only a few hectares. To locate newly infected trees in a larger area already known to be infested, we focused on smaller streams in small watersheds that could be searched on foot. Aerial survey, the core of the monitoring effort in Oregon, has only been able to detect tanoaks that are symptomatic in the upper canopy, and only after symptoms have progressed to affect the entire crown. This may be one or more years after initial infection, and the pathogen may already have spread to additional trees $(12,17)$. Several new SOD infection sites located beyond the boundaries of the main infected area were first indicated by isolation from stream baits. It typically has taken repeated ground visits to find the source of inoculum. Infected tanoak sprouts, often beneath a mature tree with early symptoms of SOD or not visible to aerial surveyors, usually were found first. Infection sites first found from stream monitoring typically had only one or two infected trees, and these were often still living or in the understory. In comparison, sites first detected from the air had at least one dead tree as well as nearby infected trees that were still alive.

Our methods have evolved with time. Initially all samples were subjected to both isolation and multiplex PCR diagnosis. PCR indicated a higher frequency of infestation by $P$. ramorum than we could confirm by isolation, although the methods generally gave congruent results (Table 1). Now we routinely rely on PCR without isolation for detection in leaf bait samples from streams that have not tested positive in the past. If a positive PCR result is obtained, we isolate from bait leaves in subsequent samples to confirm the presence of $P$. ramorum in the stream. If there are no further positive samples, then the diagnostic assay for that stream reverts to multiplex PCR only. Any positive isolation result, as well as repeat positive PCR results, triggers a ground search for symptomatic plants. All regulatory decisions in Oregon are based on isolation of $P$. ramorum from diseased plants.

The reliability of molecular diagnostic tests is always subject to question. In our work, false negative PCR results were rare, and presumably came from sampling noninfected tissues on the original leaf baits. PCR positive, isolation negative results are more frequent, and have additional possible explanations.

The primers used for our multiplex PCR detection of $P$. ramorum were first developed for identification of $P$. lateralis (25). Because of the close phylogenetic relationship between $P$. lateralis and $P$. ramorum and, therefore, the similarity of DNA sequences in the target areas of the internal transcribed spacer (ITS) region, the $P$. lateralis primers also consistently amplify
$P$. ramorum ITS DNA (25). While $P$. lateralis is present on Port-Orford-cedar in southwest Oregon forests, it has not been found within the $P$. ramorum quarantine area, and the two Phytophthora species are readily distinguished in culture based on growth characters. The multiplex PCR assay also cross-reacts with the closely related $P$. hibernalis (data not shown). Sequencing the complete PCR product distinguished these species from $P$. ramorum. False PCR positive results due to probable cross reactions with $P$. lateralis and $P$. hibernalis occurred only once for each species.

Streams WA 38 and WA 39 illustrated the diagnostic problem. Since March 2004, leaf baits from both streams consistently tested positive by multiplex PCR but negative by isolation, and no infected trees were found in repeated aerial and ground surveys. The streams are well north of the known area of SOD infestation (Fig. 1). The PCR products from samples from each stream were sequenced. The product from WA 38 matched $P$. lateralis, not $P$. ramorum. It is likely that $P$. lateralis was present in this stream, despite our failure to culture this pathogen or to locate cedar trees in the watershed. The product from WA 39 matched $P$. hibernalis, but again, no source of inoculum was identified. Detection surveys stemming from stream monitoring in forests are guided by multiplex PCR, but sudden oak death regulatory actions in Oregon are normally based only on isolation results, and stands in these watersheds are intensively monitored, but remain untreated.

There are other species of Phytophthora in forest streams, including the very abundant $P$. gonapodyides $(3,11)$, and species of Phytophthora other than P. ramorum were recovered regularly during our monitoring efforts. Most failures to isolate $P$. ramorum from bait leaves when PCR results indicated its presence probably resulted from competition between $P$. ramorum and these other more abundant and faster growing Phytophthora species.

Table 3. Monthly detection over 4 years of Phytophthora ramorum and other species of Phytophthora by isolation on selective medium and by multiplex polymerase chain reaction (PCR) in leaves used to bait stream WA 65 in Curry County, OR ${ }^{\text {a }}$

\begin{tabular}{|c|c|c|c|c|c|c|c|c|c|c|c|c|c|c|}
\hline Year & Method & Detected $^{b}$ & Jan & Feb & Mar & Apr & May & Jun & Jul & Aug & Sep & Oct & Nov & Dec \\
\hline \multirow[t]{3}{*}{2004} & PCR & P. ramorum & - & - & - & - & neg & neg & neg & neg & - & - & neg & neg \\
\hline & Isolation & P. ramorum & - & - & - & - & neg & neg & neg & $\mathrm{NP}$ & - & - & $\mathrm{NP}$ & neg \\
\hline & & Phytophthora spp. & - & - & - & - & pos & pos & pos & NP & - & - & NP & pos \\
\hline \multirow[t]{3}{*}{2005} & PCR & P. ramorum & neg & neg & neg & neg & neg & neg & neg & neg & neg & POS & neg & neg \\
\hline & Isolation & P. ramorum & neg & neg & neg & neg & neg & neg & NP & $\mathrm{NP}$ & $\mathrm{NP}$ & POS & $\mathrm{NP}$ & NP \\
\hline & & Phytophthora spp. & neg & neg & neg & neg & pos & pos & NP & NP & NP & pos & NP & NP \\
\hline \multirow[t]{3}{*}{2006} & PCR & P. ramorum & neg & neg & neg & neg & POS & neg & neg & POS & neg & POS & neg & neg \\
\hline & Isolation & P. ramorum & $\mathrm{NP}$ & $\mathrm{NP}$ & $\mathrm{NP}$ & $\mathrm{NP}$ & $\mathrm{NP}$ & $\mathrm{NP}$ & $\mathrm{NP}$ & $\mathrm{NP}$ & neg & neg & neg & neg \\
\hline & & Phytophthora spp. & NP & NP & NP & NP & NP & NP & NP & NP & pos & pos & pos & neg \\
\hline \multirow[t]{3}{*}{2007} & PCR & P. ramorum & neg & POS & neg & neg & POS & POS & POS & POS & neg & neg & neg & neg \\
\hline & Isolation & P. ramorum & neg & POS & neg & neg & neg & neg & POS & neg & neg & $\mathrm{NP}$ & $\mathrm{NP}$ & $\mathrm{NP}$ \\
\hline & & Phytophthora spp. & neg & pos & neg & pos & pos & pos & pos & pos & pos & NP & $\mathrm{NP}$ & NP \\
\hline
\end{tabular}

${ }^{\mathrm{a}}$ In most months, two sample intervals are combined. neg $=$ negative, no species of Phytophthora was detected; POS $=$ P. ramorum was detected; pos $=$ another Phytophthora species was detected; NP = not plated, isolation not attempted; - = no sample was tested.

${ }^{\mathrm{b}}$ Species of Phytophthora detected by PCR or isolation on selective medium. 
Occasionally streams tested positive for $P$. ramorum by $\mathrm{PCR}$ one time, and then never again. Rarely, the pathogen was isolated once, and then not again. These results triggered an initial ground search of the watershed for infected plants, but if that proved negative, then stream monitoring continued. The anomalous results may represent false positive PCR results or perhaps ephemeral airborne inoculum entering the stream directly.

Where $P$. ramorum was relatively abundant, as in streams draining former eradication sites where the pathogen was once well established, it was recovered at all times of the year, even though recovery rates were highest in the summer. In newly detected infested streams, on sites where inoculum remained low, the seasonal effect was stronger. More frequent detection in summer months corresponded with warmer water temperatures, and with low flow rates in these streams. Most streams monitored in Oregon have a steep topographic gradient and drain forested watersheds. Air temperatures are moderate yearround, and average water temperatures in baited streams range from about $8^{\circ} \mathrm{C}$ in winter to $15^{\circ} \mathrm{C}$ in summer, which is well within the range for active growth of $P$. ramorum (5). However, stream flow rates vary more dramatically between seasons. Flow was not measured on individual streams, but seasonal changes were obvious. Flows dropped dramatically in the dry summer months and increased rapidly during winter rainstorms. The flow of the Chetco River, which passes through the quarantine area, is monitored continuously by the U.S. Geological Survey (site no. 14400000; http://waterdata.usgs.gov/or/ nwis/) and illustrated the seasonal variation in stream flow in this part of Oregon. Monthly mean flow of the Chetco (1970 to 2008) varied about 50-fold, from $3.3 \mathrm{~m}^{3} \mathrm{~s}^{-1}$ in August to $153 \mathrm{~m}^{3} \mathrm{~s}^{-1}$ in December. It seems likely that the higher recovery of $P$. ramorum in the summer than in the winter from these mountain streams with moderate temperatures year-round resulted from low stream flow in summer. Rain events and sporulation occur in all months in this wet coastal environment (data not shown). Perhaps inoculum is diluted by the greater volume of water during high winter flows, thus reducing the probability of baiting success.

The source of inoculum entering streams in areas receiving eradication treatments remains unknown. Infected plants have not been found on these sites since 2003, despite repeated surveys (12), but the pathogen can be recovered from the soil at a low frequency. Perhaps persistent soilborne inoculum (6), including infected roots (20), maintains the population and provides continuous input to the streams. It is important to note that new infection sites in Oregon have not been traced to inoculum in stream water.

In summary, stream baiting continues to be a useful part of the SOD detection and eradication effort in Oregon. When supported by intensive follow-up ground survey, it can lead to early detection of new areas of infestation. At very early stages of infestation in a tanoak stand, detections from stream baits are infrequent. Continuous sampling increases the chances of very early detection, and therefore of successful eradication. When inoculum is relatively abundant, as in the five streams draining old eradication sites (Table 2), sampling at longer intervals may be adequate for detection.

\section{ACKNOWLEDGMENTS}

Funding for Oregon stream monitoring comes from the USDA Forest Service. The field assistance of Harvey Timeus and the Oregon Department of Forestry field crew was essential to the success of the stream monitoring program.

\section{LITERATURE CITED}

1. Alexander, J. 2006. Review of Phytophthora ramorum in European and North American nurseries. Pages 37-39 in: Proc. Sudden Oak Death 2nd Sci. Sympos.: State of Our Knowledge. S. J. Frankel, P. J. Shea, M. I. Haverty, tech. coord. U.S. Dep. Agric. For. Serv. Gen. Tech. Rep. PSW-GTR-196. Albany, CA.

2. Brasier, C., Denman, S., Brown, A., and Webber, J. 2004. Sudden Oak Death (Phytophthora ramorum) discovered on trees in Europe. Mycol. Res. 108:1108-1110.

3. Brasier, C. M., Hamm, P. B., and Hansen, E. M. 1993. Cultural characters, protein patterns and unusual mating behavior of Phytophthora gonapodyides isolates from Britain and North America. Mycol. Res. 97:1287-1298.

4. Davidson, J. M., Wickland, A. C., Patterson, H. A., Falk, K. R., and Rizzo, D. M. 2005. Transmission of Phytophthora ramorum in mixed-evergreen forest in California. Phytopathology 95:587-596.

5. Englander, L., Browning, M., and Tooley, P. W. 2006. Growth and sporulation of Phytophthora ramorum in vitro in response to temperature and light. Mycologia 98:365-373.

6. Fichtner, E. J., Lynch, S. C., and Rizzo, D. M. 2007. Detection, distribution, sporulation, and survival of Phytophthora ramorum in a California redwood-tanoak forest soil. Phytopathology 97:1366-1375.

7. Franklin, J. F., and Dyrness, C. T. 1988. Natural Vegetation of Washington and Oregon, 2nd ed. Oregon State University Press, Corvallis.

8. Goheen, E. M., Hansen, E. M., Kanaskie, A., McWilliams, M. G., Osterbauer, N., and Sutton, W. 2002. Sudden oak death caused by Phytophthora ramorum in Oregon. Plant Dis. 86:441.

9. Goheen, E., Kanaskie, A., McWilliams, M., Hansen, E., Sutton, W., and Osterbauer, N. 2006. Surveying and Monitoring Sudden Oak Death in Southwest Oregon Forests. Pages 413-415 in: Proc. Sudden Oak Death 2nd Sci. Sympos.: State of Our Knowledge. S. J. Frankel, P. J. Shea, M. I. Haverty, tech. coord. U.S. Dep. Agric. For. Serv. Gen. Tech. Rep. PSW-GTR-196. Albany, CA.

10. Hansen, E. 2007. Alien forest pathogens: Phytophthora species are changing world forests. Boreal Environ. Res. 13:33-41.

11. Hansen, E. M., and Delatour, C. 1999. Phytophthora species in oak forests of north-east France. Ann. For. Sci. 56:539-547.
12. Hansen, E. M., Kanaskie, A., Prospero, S McWilliams, M., Goheen, E. M., Osterbauer, N., Reeser, P., and Sutton, W. 2008. Epidemiology of Phytophthora ramorum in Oregon tanoak forests. Can. J. For. Res. 38:1133-1143.

13. Hansen, E. M., Parke J. L., and Sutton, W. 2005. Susceptibility of Oregon forest trees and shrubs to Phytophthora ramorum: A comparison of artificial inoculation and natural infection. Plant Dis. 89:63-70.

14. Hansen, E. M., Reeser, P. W., Sutton, W., Winton, L. M., and Osterbauer, N. 2003. First report of A1 mating type of Phytophthora ramorum in North America. Plant Dis. 87:1267.

15. Hong, C. X., and. Moorman, G. W. 2005. Plant pathogens in irrigation water: Challenges and opportunities. Crit. Rev. Plant Sci. 24:189-208.

16. Kanaskie, A., Goheen, E., Osterbauer, N., McWilliams, M., Hansen, E., and Sutton, W. 2008. Sudden oak death in Oregon forests: Status of the eradication effort. Pages 15-18 in: Proc. Sudden Oak Death 3rd Science Sympos. S. J. Frankel, J. T. Kleijunas, K. M. Palmieri, M. Katharine, tech. coord. U.S. Dep. Agric. For. Ser. Gen Tech. Rep. PSW-GTR-214. Albany, CA.

17. McPherson, B. A., Mori, S. R., Wood, D. L., Storer, A. J., Svihra, P., Kelly, N. M., and Standiford, R. B. 2006. Sudden oak death in California: Disease progression in oaks and tanoaks. Forest Ecol. Manag. 213:71-89.

18. Murphy, S. K., Bienapfl, J., Rizzo, D., Valachovic, Y., and Lee, C. 2006. Monitoring Phytophthora ramorum distribution in streams within coastal California watersheds. Page 531 in: Proc. Sudden Oak Death 2nd Sci. Sympos. State of Our Knowledge. S. J. Frankel, P. J. Shea, M. I. Haverty, tech. coord. U.S. Dep. Agric. For. Ser. Gen. Tech. Rep. PSW-GTR-196. Albany, CA.

19. Oak, S., Hwang, J., Jeffers, S., and Tkacz, B. 2008. Pilot survey for Phytophthora ramorum in forest streams in the USA. P 59-63 in: Proc. Sudden Oak Death 3rd Science Sympos. S. J. Frankel, J. T. Kleijunas, K. M. Palmieri, M. Katharine, tech. coord. U.S. Dep. Agric. For. Ser. Gen Tech. Rep. PSW-GTR-214. Albany, CA

20. Parke, J. L., and Lewis, C. 2007. Root and stem infection of rhododendron from potting medium infested with Phytophthora ramorum. Plant Dis. 91:1265-1270.

21. Rizzo, D. M., Garbelotto, M., Davidson, J. M., Slaughter, G. W., and Koike, S. T. 2002. Phytophthora ramorum as the cause of extensive mortality of Quercus spp. and Lithocarpus densiflorus in California. Plant Dis. 86:205-214.

22. Rizzo, D. M., Garbelotto, M., and Hansen, E. M. 2005. Phytophthora ramorum: Integrative research and management of an emerging pathogen in California and Oregon forests. Annu. Rev. Phytopathol. 43:309-345.

23. Sutton, W., Hansen, E., Reeser, P., and Kanaskie, A. 2008. Stream monitoring for detection of Phytophthora ramorum in Oregon. Pages 467-471 in: Proc. Sudden Oak Death 3rd Science Sympos. S. J. Frankel, J. T. Kleijunas, K. M. Palmieri, M. Katharine, tech. coord. U.S. Dep. Agric. For. Ser. Gen Tech. Rep. PSW-GTR-214. Albany, CA.

24. Werres, S., Marwitz, R., Man In't Veld, W. A., De Cock, A. W. A. M., Bonants, P. J. M., De Weerdt, M., Themann, K., Illieva, E., and Baayen, R. P. 2001. Phytophthora ramorum sp. nov., a new pathogen on Rhododendron and Viburnum. Mycol. Res. 105:1155-1165.

25. Winton, L. M., and Hansen, E. M. 2001. Molecular diagnosis of Phytophthora lateralis in trees, water, and foliage baits using multiplex polymerase chain reaction. For. Pathol. 31:275-283. 